\section{Plight of Bosnia and Croatia}

SIR - These are great times for the revival and advancement of the theory of symmetry of culpability. I refer, of course, to the war in Croatia and Bosnia, and your leading article (Nature 358, $439 ; 1992)$, and the News story by Alison Abbott (358, 360; 1992). Here are some facts which would greatly improve the foundations of this theory and, accordingly, the chances for peace in Europe.

Serbs, 12 per cent of the population of the Republic of Croatia, have occupied 25 per cent of its total territory, and effectively 'cleansed' it of Croatians, Hungarians, Czechs, Slovaks and Ukrainians. Serbs, 34 per cent of the population of Bosnia and Herzegovina have occupied 60 per cent of the total territory of that state, and are effectively cleansing it of Croatians and Muslims. The problem is not agricultural 'land grabbing' (agriculture has never been a favourite subject for communists), but the Serbian quest for control of communication lines and corridors. The loss of these would render both states, Croatia and Bosnia-Herzegovina, a joke in terms of contemporary non-agricultural economy.

These remarkable Serbian achievements are a product of other initial and consequential symmetries: Fighterbombers: Serbs 600, Croats none; Tanks: Serbs 1,800, Croats none; Heavy artillery: Serbs 2,000, Croats none; Ordnance: Serbs huge stockpiles of the former Yugoslav Army and supplies through Rumania; Croats negligible initially, now carefully dosed life-line supplies breaking the UN embargo through Slovenia and Hungary; Major damaged cities: Serbia none; Croatia 10 (with a total population in excess of 400,000 ; Bosnia 8 (population in excess of $600,000)$; Ravaged cities: Serbia none; Croatia 2 (Vukovar and Petrinja).

Casualties are mounting, but for each dead Serb there are 5 dead Croatians and 20 dead Muslims (most of them civilians, women and children).

The symmetry in the domain of science should also be mentioned. Croatian scientists share the Serbian fear that "prolonged sanctions will destroy" science. Croatia, with 20 per cent of the total population of the former Yugoslavia contained some 18 per cent of registered scientists (Croatia did not need this war to apply evaluation by peer review, as Glišin hopes for Serbia, 358, 361; 1992). Croatia was forced to contribute 28 per cent of the total Yugoslav federal budget and 40 per cent of foreign hard currency earnings (1986). Croatian scientists received about 10 per cent of federal funds (1987) for research and development, yet produced up to 40 per cent of papers from the former Yugoslavia cited in the Institute for Scientific Information $\mathrm{SCl}$ ence Citation Index (SCI), and issued the only two Yugoslav scientific journals recognized by SCI (1985): Croatica Chemica Acta and Periodicum Biologorum. The cut-off of US sponsored cooperative projects and those with the European Communities (EC) is symmetrical again. Croatia has not been admitted to the EC's PHARE programme.

The theory of symmetry of culpability should also take into account the case of the Interuniversity Centre for Postgraduate Studies in Dubrovnik, a cooperative venture of 250 universities worldwide and year-round courses. As its director, Professor Kathleen Wilkes of the University of Oxford, witnessed, its building took a few well-aimed Serbian shells and burned down along with its specialized library of 25,000 volumes.

For those unfamiliar with the theory of symmetry of culpability, it was originated by Neville Chamberlain and published in Munich in 1938.

\section{Velimir Pravdić}

Ruder Bošković Institute,

PO Box 1016, Bijenička 54,

41001 Zagreb, Croatia

SIR - To write about difficulties of Serbian science and researchers and at the same time not even mention the situation of science in Bosnia, where dozens of university buildings, research institutions and libraries have been set ablaze or demolished by Serbian mortar fire, is, to say the least, hypocritical. How those burnt and demolished building compare with a $\$ 65,000$ computer? How do burnt libraries compare with the Institute of Physics receiving only 40 of its 180 subscriptions? Do you remember the scenes shown on television when a crowd of Sarajevans lining up for bread was hit by a Serbian shell? Do you remember the man lying in the puddle of blood, crying for help and stretching his hands toward the camera? That was Professor Mahmud Dikić, with whom I worked at the Mechanical Engineering Department of the University of Sarajevo, Bosnia and Herzegovina. In that attack he lost his legs. How does that compare with BITNET electronic mail lines being disconnected?

I assume that your aim was to inform us about the protests that the Serbian scientific community is trying to articulate against their government. The protest could be summarized by saying that, after the international community imposed sanctions, 70,000 students occupied the university's main building for 26 days and that all examinations were suspended until late August. What
Abbott failed to say is that this is too little, too late. She also failed to say that the Serbian scientific community is not as innocent as she suggests. There was no mention at all of the role of the Serbian Academy of Sciences and Arts and of its Memorandum (1986) in laying the ideological framework for the formation of Greater Serbia and the atrocities that have followed.

The international scientific community used to be very vocal against the suppression of human rights in Eastern Europe, but now seems to be untouched by the plight of the Bosnian people, human rights abuses and genocide. How many other nations will be put into the Serbian cleansing machine before the world's scientific community reacts?

\section{Sead Dorić}

Institut National d'Optique,

369 Rue Franquet,

Sainte-Foy, Quebec, Canada G1P 4NB

SIR - When black pictures of history are once again emerging in Bosnia and Herzegovina, where more than 100 detention or death camps for Croats and Muslims have been established by Serbians, I would have expected Serbian scientists to be concerned about their colleagues and collaborators in Bosnia and Herzegovina. But the major worry of Serbians seems to be about shortage of funding, chemicals and about a computer that has been paid for and cannot be imported to Serbia.

Which is the guilty party? The United Nations (UN) for striking back with sanctions that will affect not only Serbian researchers but also the authoritarian communist government of Serbia, or the latter for eliciting such a response from the rest of the world?

Every scientist in Serbia should understand that silence is sometimes the same as a lie or crime especially when it is expressed in such a selfish manner. "As scientists we can only protest we cannot take up guns and kill people" said Dragan Vuckovic, a Serbian scientist. What does he think about Bosnian scientists, Croats, Muslims and loyal Serbs? Are they running their experiments? No, they are not, they are fighting for their own lives and the lives of their children or starving to death in the detention camps. No change is conceivable until human rights are acknowledged in Bosnia and Herzegovina, and until they are willing to help their colleagues to stop the bloodshed.

The UN must exert a stronger embargo on Serbia, in the hope that in the near future science would be restarted in a fair and democratic environment.

\section{Ivan Dikic}

NYU Medical Center,

550 First Avenue,

New York, New York 10016, USA 